DOI: $10.4274 /$ turkderm.09476

Turkderm-Turk Arch Dermatol Venereology 2017;51:71-7

\title{
Comorbidities in psoriasis: The recognition of psoriasis as a systemic disease and current management
}

\author{
Psoriazisde komorbiditeler: Psoriazisin sistemik hastalık olarak kabul edilmesi \\ ve güncel yaklașım
}

Göknur Kalkan

Ankara Yıldırım Beyazıt University Faculty of Medicine, Department of Dermatology, Ankara, Turkey

\begin{abstract}
Psoriasis, with a worldwide prevalence of $2-3 \%$, is now assumed as a systemic chronic inflammatory disease accompanied by comorbidities while it was accepted as a disease limited only to the skin in the past. There are several classifications of the comorbidities which are more common in patients with moderate to severe psoriasis. Simply, comorbidities can be classified as classic, emerging, related to lifestyle, related to treatment. They can also be categorized as medical comorbidities, psychiatric/psychologic comorbidities, and behaviors contributing to medical and psychiatric comorbidities. In this review, providing early diagnosis and treatment of comorbidities, learning screening recommendations for early detection and long-term disease control and improvement in life quality by integrated, multidisciplinary approach were targeted. Keywords: Psoriasis, comorbidity, systemic disease
\end{abstract}

\section{Öz}

Tüm dünyada \%2-3 oranında görülme sıklığına sahip psoriazis, geçmişte sadece deriye sınırlı kabul edilirken, günümüzde birçok komorbiditenin eşlik ettiği kronik sistemik enflamatuvar bir hastalık olarak ele alınmaktadır. Orta-şiddetli düzeyde psoriazisi olanlarda daha sık görülen komorbiditelerle ilgili çeşitli sınıflamalar mevcuttur. Basit olarak klasik, kronik sistemik enflamasyonla ilişkili, yaşam tarzı ile ilgili ve tedavi ile ilgili olarak sınıflanabileceği gibi medikal komorbiditeler, psikiyatrik/psikolojik komorbiditeler ve komorbiditelere katkı yapan durumlar şeklinde de sınıflanabilmektedir. Bu derlemede psoriazis ve eşlik eden komorbiditelerin gözden geçirilmesiyle; komorbiditelerin erken tanı ve tedavisini sağlama, komorbiditilerin erken tespitine yönelik geliştirilen tarama önerilerini öğrenme ve hastalı̆ın yönetiminde entegre, multidisipliner yaklaşım ile uzun dönem hastalık kontrolü ve hayat kalitesinde düzelme sağlamak hedeflenmektedir.

Anahtar Kelimeler: Psoriazis, komorbidite, sistemik hastalık

\section{Introduction}

Psoriasis, with a worldwide prevalence of $2-3 \%$, is now assumed as a systemic chronic inflammatory disease accompanied by comorbidities while it was accepted as a disease limited only to the skin in the past ${ }^{1}$. Psoriasis and its comorbidities were the main focused topic at several sessions of the $73^{\text {rd }}$ Annual Meeting of the American Academy of Dermatology and, especially, systemic disease concept was emphasized ${ }^{2}$. Therefore, recent publications suggest that the term psoriatic disease would be a better nomination instead of psoriasis $^{3}$. In this review, learning screening recommendations developed for early detection and treatment of comorbidities as well as integrated, multidisciplinary approach for disease management have been targeted by reviewing psoriasis and accompanying comorbidities.

Comorbidities are more frequently seen in $15 \%$ of psoriasis patients who have moderate to severe psoriasis due to increased inflammatory impact and common pathogenesis. Consistent monitoring and systemic treatment are required to prevent development of comorbidities. There are several

Address for Correspondence/Yazışma Adresi: Göknur Kalkan MD, Ankara Yıldırım Beyazıt University Faculty of Medicine, Department of Dermatology, Ankara, Turkey Phone.: +90 5052653271 E-mail: goknurkalkan@yahoo.com ORCID-ID: orcid.org/0000-0002-2358-7938

Received/Geliş Tarihi: 26.10.2016 Accepted/Kabul Tarihi: 06.01.2017

Copyright 2017 by Turkish Society of Dermatology and Venereology

Turkderm-Turkish Archives of Dermatology and Venereology published by Galenos Yayınevi. 
classifications of comorbidities in psoriasis. Although comorbidities can be simply classified as classical, related to chronic systemic inflammation, lifestyle and treatment ${ }^{4}$ (Figure 1), they can be classified as medical comorbidities, psychiatric/psychological comorbidities and conditions contributing to comorbidities (Figure 2$)^{5}$.

\section{Psoriatic arthritis}

Psoriatic arthritis is the most frequent comorbidity. This is described as inflammatory seronegative spondyloarthropathy with joint destruction. Clinical picture includes distal interphalangeal joint involvement, asymmetric oligoarthritis, symmetric polyarthritis, dactylitis, enthesitis, and spondyloarthritis, and arthritis mutilans. The prevalence in patients with psoriasis is $7-42 \%{ }^{6}$. In many patients, skin lesions precede psoriatic lesions (75\%). The prognosis varies ranging from mild joint involvement to severe erosive arthritis. Nail impairment can accompany in $90 \%$. This is a frequent comorbidity; there is undiagnosed psoriatic arthritis in many psoriasis patients. As early diagnosis and treatment would prevent erosive arthropathy and irreversible joint destruction, psoriatic patients should be screened for this condition and observed in respect of development of psoriatic arthritis ${ }^{4,7,8}$.

Pain, rigidity, swelling and tenderness of joints showing inflammatory pain, back pain and stiffness, and joint pain accompanied by morning stiffness should be especially looked for at examination. The simplest approach for diagnosis is the use of the clasification criteria for psoriatic arthritis criteria9. In case of any suspect, these patients should be referred to rheumatologist for verification of diagnosis and treatment.

\section{Obesity}

Increased prevalence and incidence of obesity were detected in psoriatic patients. In this condition, there is reciprocal correlation. Psoriasis may increase the risk of obesity. Negative psycho-social impact of psoriasis/ reduced quality of life and metabolic disorders due to nutrition habits

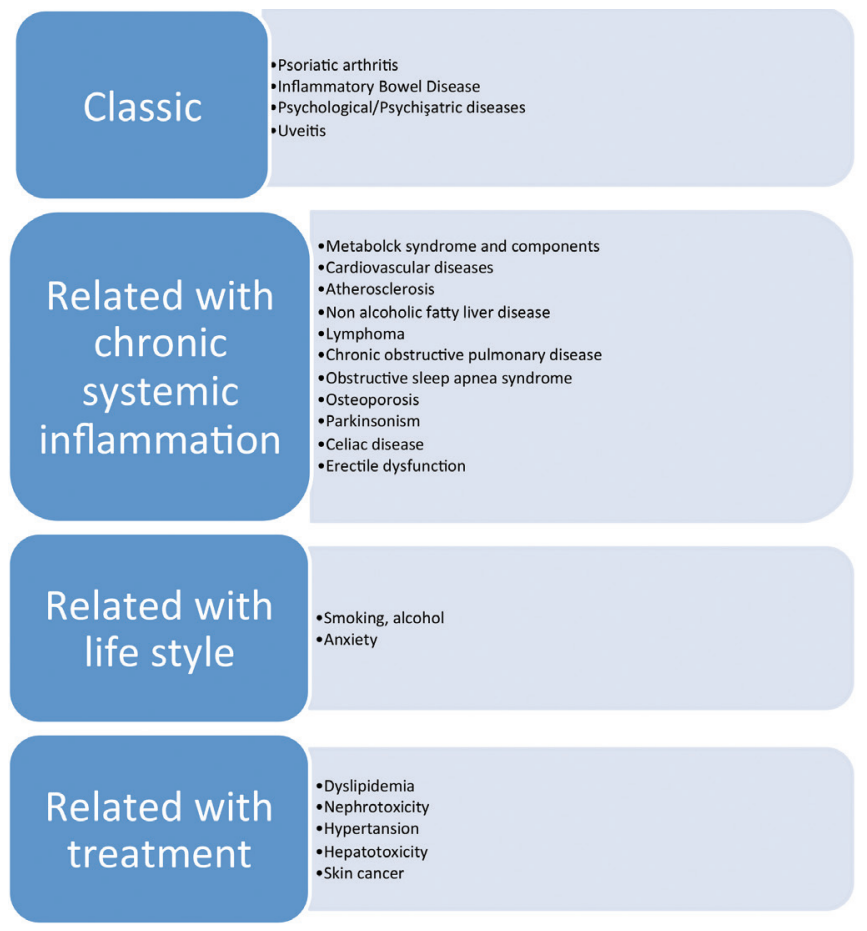

Figure 1. Classification of comorbidity-1 are considered among the causes of this condition. However, obesity may have a triggering role and may predispose to psoriasis. Chronic pro-inflammatory status, increased adipose tissue and increased body weight due to obesity, increase the risk of psoriasis ${ }^{10-12}$. The metaphor of chicken/egg relationship is used due to this close relationship between psoriasis and accompanying metabolic comorbidities ${ }^{13}$. Greater risk of obesity has been detected in patients with severe psoriasis than in those with mild disease ${ }^{14}$. Cytokines such as tumor necrosis factor (TNF)-alpha, interleukin (IL)-6, leptin, resistin, plasminogen activating inhibitor released from adipose tissue, are considered to induce psoriasis $^{15}$. Although there are studies showing reduced Psoriasis Area Severity Index (PASI) scores and increased quality of life scores following diet with low calories and gastric bypass surgery in overweight/obese patients scores, there are also studies indicating disease exacerbation following weight loss and surgery ${ }^{16-18}$. Obesity negatively affects the effect of treatment. Body weight of psoriasis patients may also affect the doses of certain therapeutic agents. This is especially significant for example in case of the usage of infliximab for which dosage is adjusted according to body weight ${ }^{19}$.

\section{Metabolic syndrome}

Metabolic syndrome itself and each of its components are risk factors for cardiovascular disease. In our country, diagnosis of metabolic syndrome is based on the "Metabolic Syndrome Diagnostic Criteria" recommended by the Turkish Association of Endocrinology and Metabolism, Metabolic Syndrome Task Force Group ${ }^{20}$. Several epidemiological studies investigated the relationship between metabolic syndrome and psoriasis and significant increase in prevalence of metabolic syndrome has been detected in psoriasis patients. The prevalence of metabolic syndrome was found to be $14 \%$ to $40 \%$ and this was especially significant in patients older than 50 years of age. A positive correlation has also been shown between disease severity and prevalence of metabolic syndrome ${ }^{21}$. In studies from Turkey, the correlation between psoriasis and metabolic syndrome has also been shown ${ }^{22}$. In respect of pathogenesis, an association of psoriasis predisposing gen loci PSORS2 PSORS3, PSORS4 and PSORS4 with metabolic syndrome, type 2 diabetes mellitus (DM), familial hyperlipidemia and cardiovascular disease predisposing gen loci has been considered. In addition, psoriasis and obesity are considered to

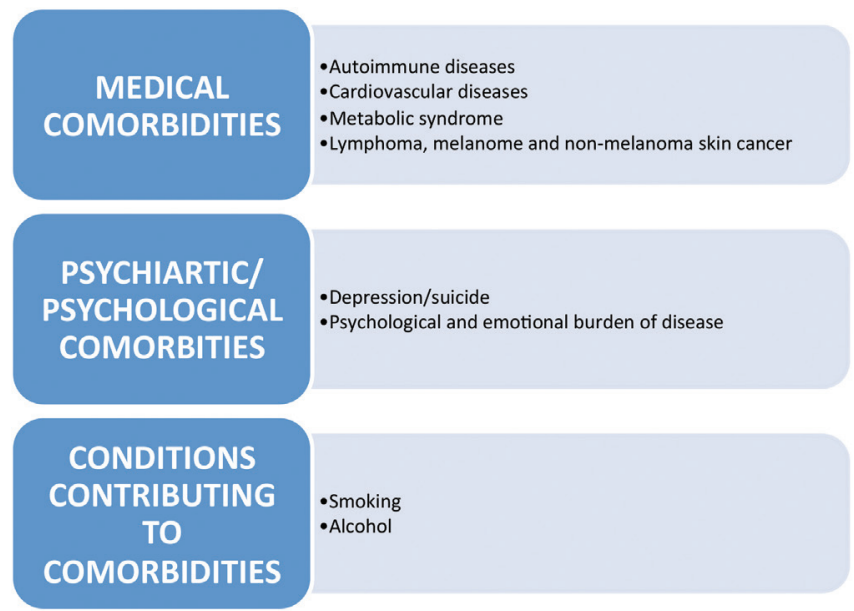

Figure 2. Classification of comorbidity-2 
contribute metabolic syndrome by affecting glucose and lipid regulation and endothelial function via cytokines and adipokines ${ }^{23}$.

\section{Diabetes mellitus}

Increased prevalence of DM has been detected in psoriatic patients. This relationship is more prominent in patients with severe psoriasis ${ }^{24}$. Psoriatic patients with DM are more likely to have micro and macrovascular complications of $\mathrm{DM}^{25}$. The need of insulin is higher in diabetic psoriatic patients due to increased level of TNF. As antiTNF agents improve insulin resistance, hypoglycemia may be seen in diabetic psoriatic patients using insulin concomitantly with anti-TNF. Hypoglycemia related with etanercept has been reported ${ }^{26}$. Therefore, dermatologists should be aware of this subject. Anti-diabetic agent group of thiazolidinedione (pioglitazone and rosiglitazone) inhibit psoriatic keratinocytes by stimulating peroxisome proliferator activating receptor gamma. A significant reduction in PASI scores was observed by pioglitazone 27 .

\section{Hypertension (HT)}

In psoriatic patients without any risk factor, the prevalence of HT was found to be higher and increased prevalence of HT was observed as disease severity increased ${ }^{28}$. Hypertensive psoriatic patients require more aggressive anti-hypertensive treatment (16.5 times more $)^{29}$. In pathophysiology, chronic inflammatory process in psoriasis increases angiotensin II, oxidative stress, endothelin-1, renin and angiotensinconverting enzyme production from adipose tissue. Since HT is a known side effect of cyclosporine, arterial pressure should be monitored in patients receiving this medicine. It should be noted that beta-blockers exacerbate psoriasis by reducing intracellular calcium level, increasing proliferation of keratinocytes and peripheral blood mononuclear leukocytes ${ }^{12,29}$.

\section{Dyslipidemia}

The association between psoriasis and dyslipidemia has been demonstrated. The prevalence of dyslipidemia is increasing by increased severity of psoriasis ${ }^{30}$. Level of cytokines mediating psoriasis such as IL-1, IL-6 and TNF-alpha and lipoprotein are altered, lipolysis is stimulated and hepatic de novo fat synthesis is stimulated. In addition, reactive oxygen species are also increased in psoriasis. Anti-TNF drugs decrease the level of inflammatory markers C-reactive protein (CRP) and lipid peroxidation products and increase serum anti-oxidant capacity $^{31}$. Retinoids increase the level of thyroglobulin, total lowdensity lipoproteins, very low-density lipoprotein cholesterol, while they decrease the level of high density lipoproteins and cyclosporine leads to hypertriglyceridemia. Statins may exacerbate or improve psoriasis ${ }^{32,33}$. A study of simvastatin showed significant reduction in PASI scores $(47.34 \%)^{34}$.

\section{Atherosclerotic disease}

Psoriasis leads to increased risk of atherosclerotic vascular disease including cardiovascular, cerebrovascular and peripheral vascular diseases, independently of age, gender and other risk factors. The increase of risk is higher in young people and patients with severe disease $^{35}$. In a retrospective study from England, 130.000 adult patients with severe psoriasis were included and psoriasis was defined as an independent risk factor for myocardial infract (MI). MI risk is higher in young patients with severe psoriasis ${ }^{36}$. Increased risk of cardiac arrhythmia has also been detected in psoriatic patients ${ }^{37}$. In psoriasis, factors contributing to development of atherosclerosis are chronic and systemic inflammation, systemic treatments, smoking habit, obesity, HT, DM, hyperlipidemia, and metabolic syndrome accompanying psoriasis ${ }^{38}$.

Early detection of atherosclerotic events is highly significant in prevention of cardiovascular events such as MI. Carotis intima media thickness (IMT) and, arterial rigidity are indicators of early/subclinical atherosclerosis ${ }^{39,40}$. In a group of psoriatic patients without cardiovascular risk factors, carotis IMT was higher ${ }^{39}$. In addition, parameters relating with arterial rigidity, such as pulse rate, are significantly increased ${ }^{40}$. Parameters are used for early diagnosis of cardiovascular impairment in psoriatic patients with normal cardiac function. Reduced coronary blood flow has been reported in young patients with severe psoriasis and was correlated with PASI score. Therefore, even in the absence of other risk factors of psoriasis, a risk factor of subclinical atherosclerosis has been pointed out ${ }^{41}$.

Most important etiopathogenesis theory is the phenomenon of psoriatic march. In psoriatic patients, insulin resistance, reduced nitric acid level and increased adhesion molecules due to systemic inflammation result in endothelial dysfunction and increase in inflammatory cells and, subsequently, atherosclerosis, coronary artery disease and MI (Figure 3) 3 . $^{42}$ Hyperhomocysteinemia identified in psoriatic patients is considered a result of excess consumption of folate required for DNA methylation of rapidly proliferating cells $s^{43}$. Hyperhomocysteinemia is an independent risk factor of vascular diseases. In psoriatic and rheumatoid arthritis (RA) patients treated by methotrexate (MTX), the risk of vascular disease is reduced due to anti-inflammatory property of the medicine. Concomitant administrations of folic acid to decrease homocysteine level, reduces even more the incidence of vascular disease in psoriasis ${ }^{44}$. $\mathrm{MI}$ risk is reduced by $55 \%$ in patients using TNF inhibitors compared to patients receiving topical/oral agents or phototherapy. TNF inhibitors are considered to be effective in prevention of $\mathrm{Ml}$ by improving endothelial function and reducing CRP and sedimentation rate. The best cardio-protective activity is reached by combination of MTX + TNF inhibitors ${ }^{45}$.

Cardiovascular and cerebrovascular mortality is remarkably higher in patients with severe psoriasis compared to that in general population.

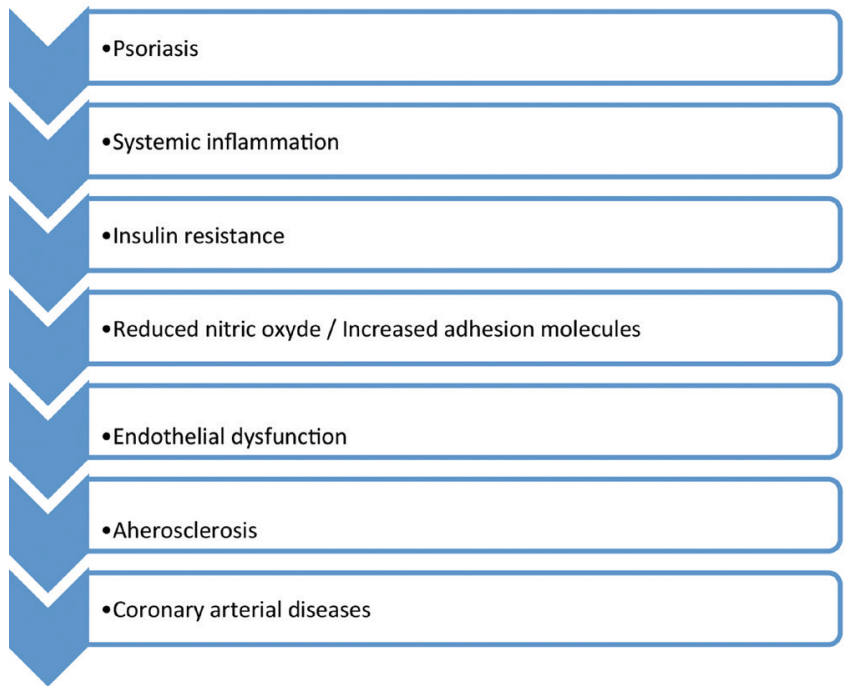

Figure 3. Psoriatic march phenomena 
Life expectancy is lower in patients with severe psoriasis ${ }^{35,46}$. Besides, there are also controversial results from other studies. Certain studies found equal cardiovascular risk with general population ${ }^{47}$. However, current guideline by the European Cardiology Association and international psoriasis organizations recognize the psoriasis as a condition increasing cardiovascular risk and suggests that patients should be managed also in this respect ${ }^{48-52}$.

\section{Malignancy}

Results of studies investigating the relationship between psoriasis and cancer are controversial. In a study including 40.987 psoriatic patients, cancer risk was found to be higher than in normal population (114/10 thousands in psoriasis patients, 95/10 thousands in general population). Mainly, the incidence of pancreatic cancer, lymphohematopoietic cancers and/lymphoma/non-melanoma skin cancer as well as colorectal, bladder, and renal cancers were also observed to be increased. A correlation between disease duration and severity and malignancy has been detected. Chronic inflammation due to psoriasis, immunosuppressive treatment, immune-modulator treatment, phototherapy, increased alcohol consumption and smoking habit are considered to trigger malignancy ${ }^{53,54}$.

\section{Non-alcoholic fatty liver disease (NAFLD)}

This is defined as excess accumulation of triglycerides without excess alcohol consumption. According to disease severity, the range of disease spectrum may be from simple fat infiltration to non-alcoholic steato-hepatitis where fibrosis, cirrhosis and rarely hepatocellular carcinoma can be seen. There is an increased risk of NAFLD in psoriatic patients, independently of obesity. Severe psoriasis and hepatic fibrosis are more frequent in patients with psoriasis and NAFLD concomitantly. In psoriasis patients, NAFLD is a significant metabolic syndrome and it is correlated with type 2 DM, dyslipidemia and psoriatic arthritis ${ }^{55,56}$. In those who have concomitantly metabolic syndrome or its components and those with 2 fold increases in liver function test, NAFLD should be suspected and expert opinion should be provided. Caution should be paid in administration of hepatotoxic drugs such as MTX. Liver disease due to MTX is more frequent in psoriasis patients than in patients with RA. Oral folate supplement has been found to reduced serum transaminase levels in patients receiving lower doses of MTX for long long-term ${ }^{57}$.

\section{Autoimmune diseases}

Frequency of autoimmune diseases is higher than in general population. In a retrospective study including 25.341 patients, highest risk was found to be related with RA, and with alopecia areata, Celiac disease, systemic sclerosis, Sjogren's syndrome, Crohn's disease (CD), vitiligo and others, in descending order ${ }^{58}$. In families with multiple sclerosis, the incidence of psoriasis is increased. In families with more than two multiple sclerosis cases, the incidence of psoriasis is even higher ${ }^{59}$.

\section{Inflammatory bowel disease (IBD)}

In psoriasis patients, the prevalence of CD and ulcerative colitis (UC) is remarkably higher ${ }^{60}$. Comorbidity risk is higher in patients with both psoriasis and IBD than in those who have only psoriasis ${ }^{61}$. Additionally, studies found higher incidence of Celiac disease in psoriasis population $^{62}$. Certain drugs, such as MTX and TNF-alpha inhibitor used in moderate/severe psoriasis, are also used in IBD $^{63}$. TNF-alpha inhibitors paradoxically induce psoriasis and side effects of drugs on gastrointestinal system can also be overlapped with $\mathrm{IBD}^{64}$.
The gene predisposing to psoriasis, CD and UC are on locus 6p21 gene. In this field, there are also IBD gene locus IBD3 and psoriasis PSORS1 locus. Th17 cells, IL-23 and IL-12B receptor genes have also been found to be correlated with psoriasis, $C D$ and $U C^{6466}$.

\section{Ocular signs and uveitis}

In psoriasis, an association with intraocular disease was also detected. The prevalence of uveitis is $2 \%$ in psoriasis. The prevalence is higher in men and in patients with late onset. There is a correlation between pustular psoriasis, psoriatic arthritis and human leukocyte antigen-B27. Uveitis accompanying psoriasis is in general occult and unless untreated, complications such as hypopyon, posterior synechiae and retinal vasculitis can develop ${ }^{67}$. In a study by Demir et al. ${ }^{68}$, deterioration in visual field was also detected in psoriatic patients. Therefore, physicians should paid pay attention to ocular signs and, ocular examination should be recommended in case of signs.

\section{Erectile dysfunction}

The prevalence of sexual/erectile dysfunction is increased in psoriatic patients. As erectile dysfunction is considered to be due to pelvic atherosclerosis, this may be an early predictor of cardiovascular diseases. The impact of depression on sexual dysfunction in psoriatic patients is controversial (non-related/positive correlation). MTX and retinoids have been were also found to be related with loss of libido and erectile dysfunction ${ }^{69,70}$.

\section{Other rare comorbidities}

These are chronic renal disease, chronic obstructive pulmonary disease, obstructive sleep apnea syndrome, osteoporosis and Parkinsonism. Study results are controversial and the number of studies is limited. The effect of inflammatory mediators is considered in the pathogenesis ${ }^{71-73}$.

\section{Psychosocial factors}

Mainly anxiety/depression and also stress (onset/exacerbation of psoriasis), lack of self-confidence/feeling guilty and unworthy, sense of shame/stigmatism, social isolation, lack of knowledge about the disease and wrong perception, sexual problems, increased suicidal thoughts, and harmful impact of the disease on quality of life can be seen in patients with psoriasis ${ }^{74,75}$. Evaluation of anxiety and depression can be simply done by two question screening. Questions should be designed to find out if they were sad, unhappy, desperate and joyless during the last month as well as if they do not like or less like to perform activities that they like before. Perception of disease should be controlled ${ }^{49}$. In a large study, behavioral cognitive therapy in addition to pharmacotherapy provided reduction in severity of psoriasis and psychological stress. In psoriasis, pro-inflammatory cytokines such as IL-1, TNF-alpha and interferon-gamma are considered to act as neuromodulator and, thus, mediate depressive disorders $49,51,74,75$.

\section{Alcohol consumption}

Alcohol consumption and alcoholism are increased in psoriatic patients. A positive correlation with severity of psoriasis has been found. The prevalence of psoriasis is also higher in those who take excess alcohol. Alcohol consumption may contribute to development of psoriasis. In the Nurses' health study (on more than 82.000 women), the frequency of psoriasis development rate was found to be higher in women consuming alcohol 2 drinks per week. Alcohol consumption has also been related to hepatic steatosis, cirrhosis, depression, increased anxiety risk, and lower response rate to psoriasis treatment ${ }^{76,77}$. 


\section{Smoking}

The inncidence and prevalence of smoking are increased in psoriasis patients. Psoriasis risk is higher in past and active smokers than in nonsmokers. Smoking habit is especially related with pustular psoriasis. Nicotine plays a role in etiopathogenesis of psoriasis by altering functional capacity of dendritic cells and inducing Th1 cytokines. Exposure as passive smoker has been associated with pediatric psoriasis. The reason is considered stimulation of nicotinic cholinergic receptors on keratinocytes ${ }^{76,78}$.

\section{Comorbidities in pediatric patients}

In $1 / 3$ of psoriasis cases, the onset is at childhood. In publications after the year 2010, an increase in pediatric comorbidity is observed. Risk factors include tobacco exposure, high body mass index (BMI), increased adipose tissue and stress. Publications point out concomitant obesity, especially. Additionally, metabolic syndrome, DM, hyperlipidemia, hypertension, rheumatoid arthritis, CD and psychiatric/ psychosocial problems are also observed. Identification of risk factors and comorbidities at this age is highly useful and risk minimization could be possible due to early changes in life style and early interventions ${ }^{79,80}$.

\section{Patient evaluation/management}

Definition of psoriasis as a systemic inflammatory disease requires a comprehensive approach for treatment. Patients with diagnosed psoriasis should be screened at the time of diagnosis and then regularly for risk factors and predictors of comorbidities and, should be referred to expert physicians when necessary. For this purpose, several international associations developed certain algorithms and check lists for the practice of dermatologists and other physicians. Multidisciplinary and integrated approach to the disease has been targeted instead of treatment in disease management. This is reached by description of accompanying diseases and adaptation of treatment according to existing comorbidities ${ }^{1-4,81}$.

\section{Patient approach}

In psoriatic patients, physical examination (body weight, height, BMI, waist circumference, arterial pressure) and calculation of severity of psoriasis (PASI/ Body Surface Area and Dermatology Life Quality Index) should be done at the time of treatment decision and especially before choosing a systemic treatment; in addition, risk factors should be questioned by screening/algorithms/check list at the time of diagnosis and at regular intervals in order to detect comorbidities. Among laboratory tests, fasting blood glucose, $\mathrm{HbA} 1 \mathrm{c}$, lipidogram, and liver and kidney function tests should be performed and in case of the presence of any sign, anxiety and depression scales should be used; sexual dysfunction and psoriatic arthritis should be investigated and monitored; cutaneous malignancies and solid tumor markers should be analyzed and ophthalmological examination should be done.

The National Psoriasis Organization Consensus Report in 2008 did proposals for comorbidity assessment. It recommended minimal screening for cardiovascular disorder, obesity, depression, infections, malignancies, psoriatic arthritis and other immune-mediated disorders. In respect of malignancy, lymphoma, cutaneous malignancies and solid tumor signs should be remembered and age-related screening, annual skin examination in those with a history of immunosuppression or psoralen and ultraviolet A, monitoring atypical plaques seen in psoriasis, lymph node examination, skin biopsy and screening for malignant melanoma and non-melanoma skin cancer in case of existence of risk factors are recommended ${ }^{50}$.

According to the American Journal of Cardiology Editor's Consensus Report 2008, patients with moderate and severe psoriasis should be informed about the increased risk of coronary heart disease and diagnostic and therapeutic analysis should be done ${ }^{82}$. The Spanish Dermatology Association Report recommends screening every 6 months in those who receive systemic treatment and annual screening in patients receiving local treatment ${ }^{52}$. Conference Report of German Dermatology Association shows the targets related with early diagnosis and treatment of psoriasis comorbidities. Definitive and practical algorithms have been created for 12 indications (HT, dyslipidemia, obesity, DM, metabolic syndrome, NAFLD, depression, alcohol, smoking, chronic IBD, psoriatic arthritis and malign lymphoma). The recommended follow-up intervals are once per year in mild psoriasis and every 6 months in severe psoriasis (including those who receive systemic treatment), in all patients with psoriatic arthritis and for malign lymphoma screening in those who receive systemic treatment. A check list at interdisciplinary level should be created for using in daily clinical practice in order to determine individual risks in patients with moderate to severe psoriasis and to create the behavioral attitude. In this respect, a practical approach should be provided by patient history, life style, smoking, alcohol consumption, physical activity status, blood analysis, 2 question screening for psychiatric interview and referring the patient to an expert physician in case of an increased risk according to the results ${ }^{49,51}$

\section{Conclusion}

Psoriasis is a chronic, life-time systemic inflammatory disease accompanied by multiple comorbidities. Integrated approach to the patient is important; in addition in the evaluation of lesions, the dermatologist should also organize the assessment of comorbidities: Diagnosis, treatment, prevention and sufficient and proper communication. In the past, the treatment of psoriasis was suppression of acute skin rash, however, current view is to recognize this disease as a chronic systemic inflammatory disease and then to reflect this concept in real life practice to perform long-term disease management and improvement in quality of life. Studies on evaluation of the effect of comorbid diseases in psoriasis and vice versa and demonstrating value and cost-effectiveness of multidisciplinary clinical programs will determine the importance of such approach.

\section{Ethic}

Peer-review: Externally peer-reviewed.

Financial Disclosure: The author declared that this study received no financial support.

\section{References}

1. Grozdev I, Korman N, Tsankov N: Psoriasis as a systemic disease. Clin Dermatol 2014;32:343-50.

2. Donigan JM: Focus on psoriasis: a report from the 73rd annual meeting of the American Academy of Dermatology. Psoriasis-related topics included targeted therapies, safety of biologies, comorbidities. J Clin Aesthet Dermatol 2015;8(Suppl 3):8-16.

3. Boehncke $\mathbf{W H}$, Boehncke S: More than skin-deep: the many dimensions of the psoriatic disease. Swiss Med Wkly 2014;144:w13968. 
4. Oliveira Mde F, Rocha Bde O, Duarte GV: Psoriasis: classical and emerging comorbidities. An Bras Dermatol 2015;90:9-20.

5. Menter A, Gottlieb A, Feldman SR, et al: Guidelines of care for the management of psoriasis and psoriatic arthritis: Section 1. Overview of psoriasis and guidelines of care for the treatment of psoriasis with biologics. J Am Acad Dermatol 2008;58:826-50.

6. Farley E, Menter A: Psoriasis: comorbidities and associations. G Ital Dermatol Venereol 2011;146:9-15.

7. Boehncke WH, Qureshi A, Merola JF, et al: Diagnosing and treating psoriatic arthritis: an update. Br J Dermatol 2014;170:772-86.

8. Radtke MA, Reich K, Blome C, Rustenbach S, Augustin M. Prevalence and clinical features of psoriatic arthritis and joint complaints in 2009 patients with psoriasis: results of a German national survey. J Eur Acad Dermatol Venereol 2009;23:683-91.

9. Taylor W, Gladman D, Helliwell , et al: Classification criteria for psoriatic arthritis. Development of new criteria from a large international study. Arthritis Rheum 2006;54:2665-73.

10. Duarte GV, Oliveira Mde F, Cardoso TM, et al: Association between obesity measured by different parameters and severity of psoriasis. Int J Dermato 2013;52:177-81.

11. Carrascosa JM, Rocamora V, Fernandez-Torres RM, et al: Obesity and psoriasis: inflammatory nature of obesity, relationship between psoriasis and obesity, and therapeutic implications. Actas Dermosifiliogr 2014;105:31-44.

12. Ni C, Chiu MW: Psoriasis and comorbidities: links and risks. Clin Cosme Investig Dermatol 2014;7:119-32

13. Dalamaga M, Papadavid E: Metabolic co-morbidities and psoriasis: The chicken or the egg? World J Dermatol 2013;2:32-5.

14. Armstrong AW, Harskamp CT, Armstrong EJ: The association between psoriasis and obesity: a systematic review and meta-analysis of observational studies. Nutr Diabetes 2012;2:e54.

15. Gerdes S, Rostami-Yazdi M, Mrowietz U: Adipokines and psoriasis. Exp Dermatol 2011;20:81-7

16. Jensen $P$, Zachariae $C$, Christensen $R$, et al: Effect of weight loss on the severity of psoriasis: a randomized clinical study. JAMA Dermatol 2013;149:795-801.

17. de Menezes Ettinger JE, Azaro E, de Souza CA, et al: Remission of psoriasis after open gastric bypass. Obes Surg 2006;16:94-7

18. Pérez-Pérez L, Allegue F, Caeiro JL, Zulaica JM: Severe psoriasis, morbid obesity and bariatric surgery. Clin Exp Dermatol 2009:34:421-2.

19. Naldi L, Addis A, Chimenti S, et al: Impact of body mass index and obesity on clinical response to systemic treatment for psoriasis. Evidence from the Psocare project. Dermatology 2008;217:365-73.

20. Metabolik sendrom kılavuzu. Türkiye Endokrinoloji ve Metabolizma Derneğ 2009.

21. Armstrong AW, Harskamp CT, Armstrong EJ: Psoriasis and metabolic syndrome: a systematic review and meta-analysis of observational studies. J Am Acad Dermatol 2013;68:654-62.

22. Akcali C, Buyukcelik B, Kirtak N, Inaloz S: Clinical and laboratory parameters associated with metabolic syndrome in Turkish patients with psoriasis. J Int Med Res 2014;42:386-94.

23. Aurangabadkar SJ: Comorbidities in psoriasis. Indian J Dermatol Venereo Leprol 2013;79(Suppl 7):10-7

24. Armstrong AW, Harskamp $C T$, Armstrong EJ: Psoriasis and the risk of diabetes mellitus: a systematic review and meta-analysis. JAMA Dermatol 2013;149:84-91.

25. Armstrong AW, Guérin A, Sundaram M, et al: Psoriasis and risk of diabetesassociated microvascular and macrovascular complications. J Am Acad Dermatol 2015;72:968-77.

26. Farrokhi F, Taylor HC, McBride NM: Etanercept-induced hypoglycemia and improved glycemic control in a patient with type 2 diabetes. Endocr Pract 2011;17:306-7

27. Malhotra A, Shafiq N, Rajagopalan S, Dogra S, Malhotra S: Thiazolidinediones for plaque psoriasis: a systematic review and meta-analysis. Evid Based Med 2012;17:171-6

28. Armstrong AW, Harskamp $\mathrm{CT}$, Armstrong EJ: The association between psoriasis and hypertension: a systematic review and meta-analysis of observational studies. J Hypertens 2013;31:433-42.

29. Armstrong AW, Lin SW, Chambers CJ, Sockolov ME, Chin DL: Psoriasis and hypertension severity: results from a case-control study. PLoS One 2011;6:e18227

30. Ma C, Harskamp CT, Armstrong EJ, Armstrong AW: The association between psoriasis and dyslipidaemia: a systematic review. $\mathrm{Br} J$ Dermatol 2013;168:486-95.
31. Bacchetti T, Campanati A, Ferretti G, Simonetti O, Liberati G, Offidani AM: Oxidative stress and psoriasis: the effect of antitumour necrosis factorinhibitor treatment. Br J Dermatol 2013;168:984-9.

32. Corbetta S, Angioni R, Cattaneo A, Beck-Peccoz P, Spada A: Effects of retinoid therapy on insulin sensitivity, lipid profile and circulating adipocytokines. Eur Jndocrinol 2006:154:83-6.

33. Grossman RM, Delaney RJ, Brinton EA, Carter DM, Gottlieb AB: Hypertriglyceridemia in patients with psoriasis treated with cyclosporine. Am Acad Dermatol 1991;25:648-51

34. Shirinsky IV, Shirinsky VS: Efficacy of simvastatin in plaque psoriasis: a pilot study. J Am Acad Dermatol 2007;57:529-31.

35. Prodanovich S, Kirsner RS, Kravetz JD, Ma F, Martinez L, Federman DG: Association of psoriasis with coronary artery, cerebrovascular, and periphera vascular diseases and mortality. Arch Dermatol 2009;145:700-3.

36. Gelfand JM, Neimann AL, Shin DB, Wang X, Margolis DJ, Troxel AB: Risk of myocardial infarction in patients with psoriasis. JAMA 2006;296:1735-41.

37. Chiu HY, Chang WL, Huang WF, Wen YW, Tsai YW, Tsai TF: Increased risk of arrhythmia in patients with psoriatic disease: A nationwide population-based matched cohort study. J Am Acad Dermatol 2015;73:429-38.

38. Reich K: The concept of psoriasis as a systemic inflammation: implications for disease management. J Eur Acad Dermatol Venereol 2012;26(Suppl 2):311.

39. Lorenz MW, Markus HS, Bots ML, Rosvall M, Sitzer M: Prediction of clinical cardiovascular events with carotid intima-media thickness: a systematic review and meta-analysis. Circulation 2007;115:459-67.

40. Balta I, Balta S, Demirkol S, et al: Aortic arterial stiffness is a moderate predictor of cardiovascular disease in patients with psoriasis vulgaris Angiology 2014;65:74-8.

41. Osto E, Piaserico S, Maddalozzo A, et al: Impaired coronary flow reserve in young patients affected by severe psoriasis. Atherosclerosis 2012;221:1137.

42. Boehncke WH, Boehncke S, Tobin AM, Kirby B: The 'psoriatic march': a concept of how severe psoriasis may drive cardiovascular comorbidity. Exp Dermatol 2011;20:303-7.

43. Malerba M, Gisondi P, Radaeli A, Sala R, Calzavara Pinton PG, Girolomoni G: Plasma homocysteine and folate levels in patients with chronic plaque psoriasis. Br J Dermatol 2006;155:1165-9.

44. Prodanovich S, Ma F, Taylor JR, Pezon C, Fasihi T, Kirsner RS: Methotrexate reduces incidence of vascular diseases in veterans with psoriasis or rheumatoid arthritis. J Am Acad Dermatol 2005;52:262-7

45. Wu JJ, Poon KY: Association of gender, tumor necrosis factor inhibitor therapy, and myocardial infarction risk in patients with psoriasis. J Am Acad Dermatol 2013;69:650-1.

46. Mehta NN, Yu Y, Pinnelas $R$, et al: Attributable risk estimate of severe psoriasis on major cardiovascular events. Am J Med 2011;124:775.

47. Parisi R, Rutter MK, Lunt M, et al: Psoriasis and the risk of major cardiovascular events: cohort study using the clinical practice research datalink. J Invest Dermatol 2015;135:2189-97.

48. Perk J, De Backer G, Gohlke H, et al: European Guidelines on cardiovascular disease prevention in clinical practice (version 2012). The Fifth Joint Task Force of the European Society of Cardiology and Other Societies on Cardiovascular Disease Prevention in Clinical Practice (constituted by representatives of nine societies and by invited experts). Eur Heart J 2012;33:1635-701.

49. Wohlrab J, Fiedler G, Gerdes S, et al: Recommendations for detection of individual risk for comorbidities in patients with psoriasis. Arch Dermatol Res 2013:305:91-8.

50. Kimball AB, Gladman D, Gelfand JM, et al: National Psoriasis Foundation clinical consensus on psoriasis comorbidities and recommendations for screening. J Am Acad Dermatol 2008;58:1031-42.

51. Radtke MA, Mrowietz U, Feuerhahn J, et al: Early detection of comorbidity in psoriazis: recommendations of the National Conference on Healthcare in Psoriasis. J Dtsch Dermatol Ges 2015;13:674-89.

52. Daudén E, Castañeda S, Suárez C, et al: Clinical practice guideline for an integrated approach to comorbidity in patients with psoriasis. J Eur Acad Dermatol Venereol 2013;27:1387-404.

53. Kimball AB, Schenfeld J, Accortt NA, Anthony MS, Rothman KJ, Pariser $D$ : Incidence rates of malignancies and hospitalized infectious events in patients with psoriasis with or without treatment and a general population in the U.S.A.: 2005-09. Br J Dermatol 2014;170:366-73.

54. Brauchli YB, Jick SS, Miret M, Meier CR: Psoriasis and risk of incident cancer: an inception cohort study with a nested case-control analysis. J Invest Dermatol 2009:129:2604-12. 
55. Gisondi P, Targher G, Zoppini G, Girolomoni G: Non-alcoholic fatty liver disease in patients with chronic plaque psoriasis. J Hepatol 2009;51:758-64.

56. Miele L, Vallone S, Cefalo C, et al: Prevalence, characteristics and severity of non-alcoholic fatty liver disease in patients with chronic plaque psoriasis. $J$ Hepatol 2009;51:778-86

57. Kalb RE, Strober B, Weinstein G, Lebwohl M: Methotrexate and psoriasis: 2009 National Psoriasis Foundation Consensus Conference. J Am Acad Dermatol 2009;60:824-37.

58. Wu JJ, Nguyen TU, Poon KY, Herrinton LJ: The association of psoriasis with autoimmune diseases. J Am Acad Dermatol 2012;67:924-30.

59. Broadley SA, Deans J, Sawcer SJ, Clayton D, Compston DA: Autoimmune disease in first-degree relatives of patients with multiple sclerosis. A UK survey. Brain 2000;123:1102-11.

60. Cohen AD, Dreiher J, Birkenfeld S: Psoriasis associated with ulcerative colitis and Crohn's disease. J Eur Acad Dermatol Venereol 2009;23:561-5.

61. Binus AM, Han J, Qamar AA, Mody EA, Holt EW, Qureshi AA: Associated comorbidities in psoriasis and inflammatory bowel disease. J Eur Acad Dermatol Venereol 2012;26:644-50

62. Wu JJ, Nguyen TU, Poon KY, Herrinton LJ: The association of psoriasis with autoimmune diseases. J Am Acad Dermatol 2012;67:924-30.

63. Angelucci E, Cocco A, Viscido A, Vernia P, Caprilli R: Another paradox in Crohn's disease: new onset of psoriasis in a patient receiving tumor necrosis factor-alpha antagonist. Inflamm Bowel Dis 2007;13:1059-61.

64. Aslanidis S, Pyrpasopoulou A, Douma S, Triantafyllou A: Tumor necrosis factor-a antagonist-induced psoriasis: yet another paradox in medicine. Clin Rheumatol 2008;27:377-80.

65. Wolf N, Quaranta M, Prescott NJ, et al: Psoriasis associated with pleiotropic susceptibility loci identified in type II diabetes and Crohn disease. J Med Genet 2008;45:114-6.

66. Cargill M, Schrodi SJ, Chang M, et al: A large-scale genetic association study confirms IL12B and leads to the identification of IL23R as psoriasis-risk genes. Am J Hum Genet 2007;80:273-90.

67. Fraga NA, Oliveira Mde F, Follador I, Rocha Bde O, Rego VR: Psoriasis and uveitis: a literature review. An Bras Dermatol 2012;87:877-83.

68. Demir HD, Kalkan G, Kurt S, Güneş A, Sezer E, Erkorkmaz Ü: Relationship between retinal sensitivity and disease activity in patients with psoriasis vulgaris. Clinics (Sao Paulo) 2015;70:14-7
69. Goulding JM, Price CL, Defty CL, Hulangamuwa CS, Bader E, Ahmed I: Erectile dysfunction in patients with psoriazis: increased prevalence, an unmet need, and a chance to intervene. Br J Dermatol 2011;164:103-9.

70. Meeuwis KA, de Hullu JA, van de Nieuwenhof HP, et al: Quality of life and sexual health in patients with genital psoriasis. Br J Dermatol 2011;164:124755.

71. Machado-Pinto J, Diniz Mdos S, Bavoso NC: Psoriasis: new comorbidities. An Bras Dermatol 2016;91:8-14.

72. Sheu JJ, Wang KH, Lin HC, Huang CC: Psoriasis is associated with an increased risk of parkinsonism: a population-based 5-year follow-up study. $J$ Am Acad Dermatol 2013;68:992-9.

73. Wan J, Wang S, Haynes K, Denburg MR, Shin DB, Gelfand JM: Risk of moderate to advanced kidney disease in patients with psoriasis: population based cohort study. BMJ 2013;347:f5961

74. Russo PA, Ilchef R, Cooper AJ: Psychiatric morbidity in psoriasis: a review. Australas J Dermatol 2004; 45:155-9.

75. Weiss SC, Kimball AB, Liewehr DJ, Blauvelt A, Turner ML, Emanuel EJ: Quantifying the harmful effect of psoriasis on health-related quality of life. $J$ Am Acad Dermatol 2002;47:512-8.

76. Higgins E: Alcohol, smoking and psoriasis. Clin Exp Dermatol 2000;25:10710.

77. Poikolainen K, Reunala T, Karvonen J, Lauharanta J, Kärkkäinen P: Alcohol intake: a risk factor for psoriasis in young and middle aged men? BMJ 1990; 300:780-3.

78. Naldi L, Chatenoud L, Linder D, et al: Cigarette smoking, body mass index, and stressful life events as risk factors for psoriasis: results from an Italian case-control study. J Invest Dermatol 2005;125:61-7.

79. Radtke MA, Mrowietz U, Feuerhahn J, et al: Early detection of comorbidity in psoriasis: recommendations of the National Conference on Healthcare in Psoriasis. J Dtsch Dermatol Ges 2015;13:674-90.

80. Wootton $\mathrm{Cl}$, Murphy R: Psoriasis in children: should we be worried about comorbidities? Br J Dermatol 2013;168:661-3.

81. Mrowietz U, Steinz K, Gerdes S: Psoriasis: to treat or to manage? Exp Dermatol 2014;23:705-9.

82. Friedewald VE, Cather JC, Gelfand JM, et al: AJC editor's consensus: psoriasis and coronary artery disease. Am J Cardiol 2008;102:1631-43. 